\title{
Lignin Modifications and Perspectives towards Applications of Phenolic Foams: A Review
}

\begin{abstract}
Carolina Londono-Zuluaga,* Jing Du, Hou-Min Chang, Hasan Jameel, and Ronalds Gonzalez

Lignin is a complex natural polymer and by-product of the pulp and paper industry. Currently, the increasing interest in bio-based products has motivated the search for alternative renewable feedstocks that can sustainably replace synthetic polymers. Because of the phenolic functionalities of lignin, this natural polymer has attracted interest for application in biomaterials. Among various products, polymeric foams stand out as a potential product in which lignin incorporation has resulted in improved mechanical and thermal properties. This paper reviews the state of lignin foam development, with emphasis placed on phenol-lignin types.
\end{abstract}

Keywords: Lignin; Phenol; Formaldehyde; Polymeric foams; Phenolic foam

Contact information: Department of Forest Biomaterials, North Carolina State University, Box 8005, Raleigh, NC 27695-8005 USA; *Corresponding author: clondon@ncsu.edu

\section{INTRODUCTION}

Foams are solids with void spaces known as cells (Gibson and Ashby 1997). The formation of void spaces in the solid are possible because of the dispersion of gas bubbles (discontinuous phase) in the matrix (continuous phase). The diffusion of gas in the solid phase is a key process in foam manufacturing to achieve a foam structure. Gas diffusion in the continuous phase affects the structural parameters, such as the density, cell type (open or closed), and cell size distribution, which influence the final characteristics and properties of the foams (Imeokparia et al. 2002; Eaves 2004; Lee et al. 2007).

In addition to structural parameters, the material used in foam manufacturing and the processing conditions contribute to not only the structure and final characteristics, but also determine the foam applications. In foams, polymers are widely used because of different advantageous properties. Low density of a polymer results in weight reduction, which allows for lighter foams. Low heat transfer makes polymeric foams a suitable option for insulation purposes. Also, polymers allow for the manufacturing of flexible and soft foams, which provide comfort when used in furniture (Aseeva et al. 2004).

Foams can be classified depending on the material used for manufacturing, such as polyurethane, polystyrene, poly (vinyl chloride), phenol-formaldehyde, etc. (Aseeva et al. 2004). Alternatively, they can be classified into flexible or rigid foams according to the final properties, which can define the final product applications. Flexible foams are commonly used in furnishing, aircraft, bicycles, automobiles, clothing, packaging, electronics, and other areas. Rigid foams are widely used as a thermoset material, which makes them highly valuable for insulation applications (Aseeva et al. 2004).

Today, the insulation market growth is driven by regulatory schemes, along with consumer awareness of energy efficiency and preservation. These trends are expected to 
contribute to a market that was worth 52.30 billion USD in 2017 and is expected to keep growing at a compound annual growth rate of 8.6\% from 2018 to 2025 (Grand View Research 2018). These factors represent an opportunity and challenge to improve foam thermal properties for insulation materials.

Despite the properties and multiple applications of polymeric foams as insulation, concerns about sustainable raw materials and energy efficient buildings have led to research into feedstocks from renewable resources that can perform as well as synthetic polymer-based materials or even better. As a renewable and abundant resource, lignin has attracted enormous research attention as a potential precursor for both thermosetting and thermoplastic materials. Lignin is one of the three major components in vascular plants (Grand View Research 2015) and the most abundant aromatic bio-polymer (da Silva et al. 2009). In the United States and Canada, the pulp and paper industry produces approximately 31 million tons of lignin per year (USDA 2008). However, most of the lignin generated is burned in boilers to recover inorganic pulping chemicals and generate energy, which results in limited lignin availability (approximately $2 \%$ ) for market products (Calvo-Flores and Dobado 2010).

In addition to the availability, the thermal stability that lignin possesses and its diverse functional groups, such as hydroxyl and methoxyl groups, indicate the potential compatibility in polymer blending and other composites (Stewart 2008; Doherty et al. 2011; Li and Ragauskas 2012). The production of vanillin (Araújo et al. 2010; Fache et al. 2016), carbon fibers (Mainka et al. 2015), and concrete admixtures (Bremner et al. 1997) from lignin have been reported in the literature. Also, lignin has been shown to work experimentally in phenol manufacturing (Kleinert and Barth 2008), adhesives (Ghaffar and Fan 2014; Kong et al. 2014), foams, animal feed (Knudsen 1997), emulsifying agents (Rojas et al. 2007), and heavy metal sequesters (Grand View Research 2015; Wool 2005). Many reviews are available on the utilization of lignin in different areas, such as ligninbased adhesives, polyurethane foams, and carbon fibers. However, few reviews were found concerning the application of lignin in phenolic foams. The only work related to the topic is by Obaid et al. (2016), which is a book on lignin-based foaming materials. However, the authors did not do a comprehensive review on the topic.

To understand the effect of lignin in phenolic foams, it is important to characterize foams according to their properties and structural parameters. Density refers to the polymer fraction in a matrix. A higher density is an indication that the amount of polymer is higher than the gas fraction in the matrix. If the gas phase is predominant in the foaming process, a low fraction of polymer is present in the foam. As a result, a low density and light foam is obtained. The density directly correlates to the mechanical properties. A low density leads to inferior mechanical properties and vice versa (Eaves 2004; Lee et al. 2007). Standard values for the density and mechanical properties of various foam types are given in Table 1.

Besides density, cell type is directly related to several properties, including energy absorption, insulation, sound absorption, and water retention. Because open-cell foams allow air to flux easily, it makes this type of foam suitable for gas exchange, fluid retention, absorption, sound deadening, and other similar applications (Roberts and Garboczi 2002; Lee et al. 2007). In contrast, closed-cell foams are desired for their energy absorption, sound absorption, insulation, and improved mechanical properties. Because the cells show strong resistance to air and moisture, the polymer phase dominates the matrix and provides an elastic material resistance to external disturbances (Lee et al. 2007). 
Table 1. Standards for Rigid Phenolic Foams for Insulation Purposes

\begin{tabular}{|c|c|c|c|c|c|c|c|}
\hline Property & Unit & $\begin{array}{c}\text { Type } \\
\text { I }\end{array}$ & $\begin{array}{c}\text { Type } \\
\text { II }\end{array}$ & $\begin{array}{c}\text { Type } \\
\text { III1 }\end{array}$ & $\begin{array}{c}\text { Type } \\
\text { III2 }\end{array}$ & $\begin{array}{c}\text { Type } \\
\text { III3 }\end{array}$ & $\begin{array}{c}\text { Type } \\
\text { III4 }\end{array}$ \\
\hline Density & $\mathrm{kg} / \mathrm{m}^{3}$ & $\mathrm{~N} / \mathrm{A}$ & 32 & 32 & 60 & 80 & 120 \\
\hline Compressive Resistance & $\mathrm{kPa}$ & 108 & 124 & 124 & 207 & 345 & 517 \\
\hline Tensile Strength & $\mathrm{Pa}$ & 7180 & $\mathrm{~N} / \mathrm{A}$ & $\mathrm{N} / \mathrm{A}$ & $\mathrm{N} / \mathrm{A}$ & $\mathrm{N} / \mathrm{A}$ & $\mathrm{N} / \mathrm{A}$ \\
\hline Water Absorption (by volume) & $\%$ & 3 & 3 & 3 & 3 & 3 & 3 \\
\hline $\begin{array}{c}\text { Apparent Thermal } \\
\text { Conductivity (Foam Core) at } \\
24^{\circ} \mathrm{C}\end{array}$ & $\mathrm{W} / \mathrm{m} \cdot \mathrm{K}$ & 0.025 & 0.021 & 0.026 & 0.032 & 0.033 & 0.035 \\
\hline
\end{tabular}

Type I: roof insulation board; Type II: sheathing or rigid panel; Type III: pipe insulation; ASTM C1126 (2015)

The cell size distribution has a direct impact on the mass and heat transfer. As is shown in Fig. 1, the thickness of the wall is determined by the distribution of the void spaces in the matrix, which allows or prevents the circulation of heat or mass through the material. These properties are especially important in certain areas, including insulation, packaging materials, and medical devices (Lee et al. 2007).

This review mainly focused on the utilization of lignin in rigid phenolic foams. Lignin use in phenolic foams often follows one of two approaches: 1) direct use in the synthesis process without any preliminary chemical modification and 2) chemical modification of the lignin structure before use in foam preparations.

The aim of this work was to provide a brief overview of rigid lignin-based phenolic foams and the various applications that could potentially benefit from lignin incorporation. Additionally, this review highlights the importance of bio-based products on real market trends.

\section{PHENOLIC FOAMS}

Phenolic compounds are widely used in different products like adhesives and foams. In general, polystyrene and urethane foams are preferred because of their density and thermal conductivity. However, the generation of toxic gases during combustion has led to phenolic foams potentially replacing these foams. Unlike other foams, the properties of low flammability and outstanding fire and chemical resistance make phenolic foams highly suitable for insulation purposes (Kim and Lee 2008; Hu et al. 2012; Markets and Markets 2015).

\section{Phenol-formaldehyde Synthesis}

Phenol-formaldehyde (PF) resins can be synthesized in either an acidic or alkaline medium (Fig. 2). (Gardiziella et al. 2015). In addition to their use as adhesives, PF resins are the basic component of low-density PF foams that have a low thermal conductivity and high service temperature (Obaid et al. 2016). Synthesis begins when phenol and formaldehyde are mixed in a solution at a low pressure and high temperature. During this reaction, the double-bonded carbonyl group in formaldehyde facilitates crosslinking with phenol in an acid- or base-catalyzed reaction. The pathway of this reaction depends on the formaldehyde concentration and process conditions. 
Acid-catalysed reactions:

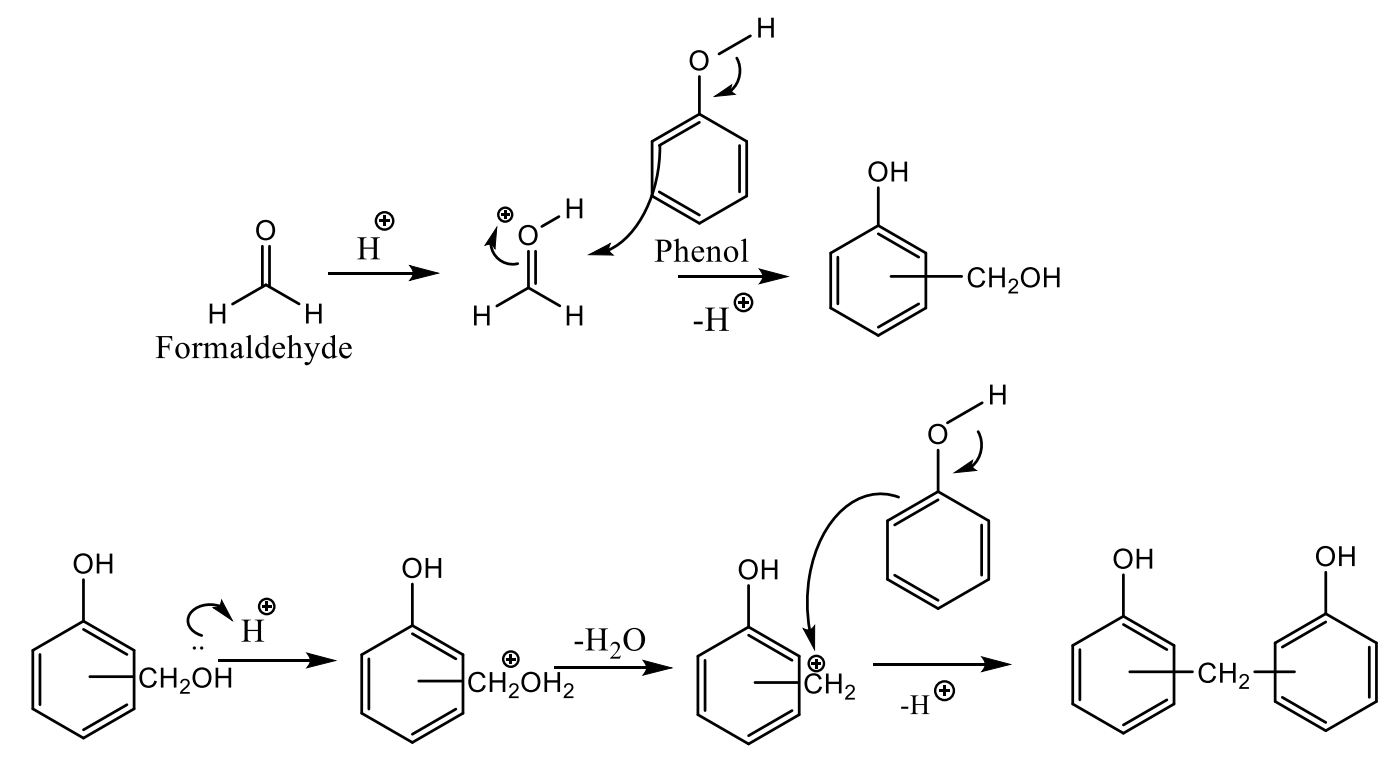

Alkaline-catalysed reactions:
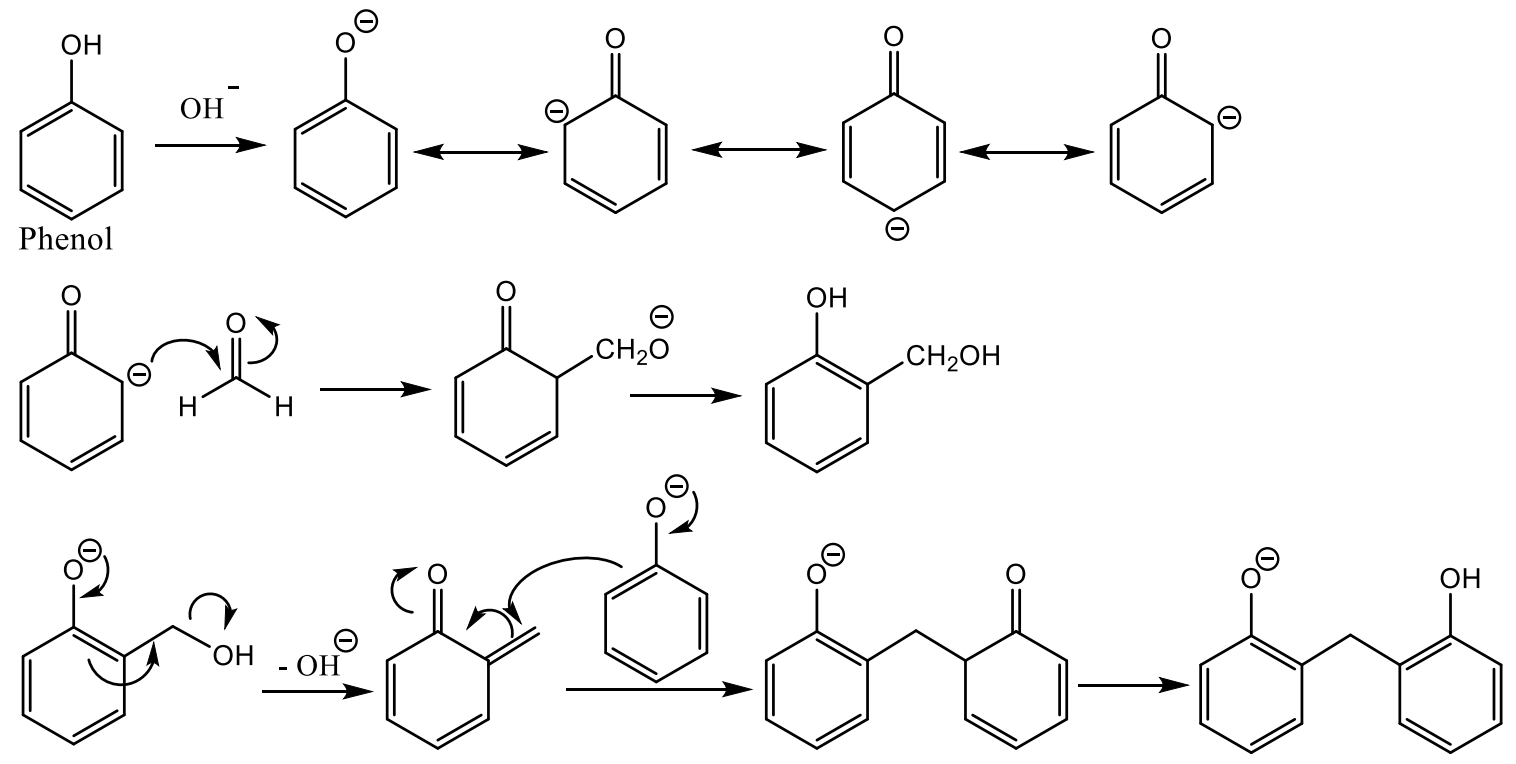

Fig. 2. Reaction pathway for acid- and base-catalyzed PF resins

\section{Preparation of Phenol-formaldehyde Foams}

In Phenol Formaldehyde (PF) foams, each component plays a key role in the foaming reaction. Basic components include a PF resole, blowing agent surfactant, and curing agent. PF resoles provide the solid matrix for gas diffusion and cellular structure formation. Their use in foams is limited by the solid content. The optimum resole solid content in foam preparations is $80 \%$. Before using PF resoles, the excess water is evaporated (Quarles and Baumann 1967; Rastall et al. 1985).

In contrast, a blowing agent is added to assist foam formation. The blowing agent is commonly introduced to the formulation in a liquid state and has a relatively low boiling 
point. Expansion of the blowing agent can produce a cellular structure during the foaming process because of its evaporation. During the preparation of phenolic foams, blowing agents can be used alone or in combination with a curing agent depending on the desired final density of the foam. For phenolic foam production, $N$-pentane is commonly used (Del Saz-Orozco et al. 2012; Del Saz-Orozco et al. 2015). In combination with resoles and blowing agents, surfactants are used to modify the characteristics of the polymer matrix during the foam formation process. They are used to emulsify the liquid components, regulate cell size, and stabilize the cell structure to prevent collapse and surface defects. In phenolic foam production, Tween 40 (polyoxyethylene (20) sorbitan monopalmitate) and Tween 80 (polyoxyethylene (20) sorbitan monooleate) are the most commonly used surfactants (Lee et al. 2002; Hu et al. 2012, 2013). Finally, the phenolic foam forming reaction is catalyzed with a curing agent, such as an acid like sulfuric or hydrochloric acid (Zhuang et al. 2011). Part of the acid works to neutralize the sodium hydroxide used in the resoles preparation process and the rest functions as a catalyst to lower the activation energy for the crosslinking reactions of PF resoles (Lee et al. 2002).

\section{LIGNIN MODIFICATION}

Lignin can be described as a complex, aromatic and highly branched heterogeneous polymer (Boerjan et al. 2003; Vanholme et al. 2010) composed of multiple functional groups, such as hydroxyl and methoxyl groups, along with a phenolic backbone. A generic representation of a monomeric building block within lignin can be seen in Fig. 3. Variations on lignin monomer are due to methoxylation of the hydroxylcinnamyl alcohol in the $\mathrm{C} 3$ and C5 positions; resulting in the formation of monolignols that originate the guaiacyl $(\mathrm{G})$, syringyl (S) and p-hydroxyphenyl (H) units (Vanholme et al. 2010)

Within unmodified lignin of hardwood species, the C5 position is substituted with a second methoxyl group. In addition, the phenol-propane units are often linked to each other by means of various covalent bonds originating at the $\alpha$ and $\beta$ positions. Some other branch points within lignin involve the 4 position. (Laurichesse and Avérous. 2014). i.e. the phenolic hydroxyl; such connections within the lignin polymer greatly decrease the number of phenolic - $\mathrm{OH}$ groups that might be theoretically anticipated. The functional groups indicated in the figure are the most important groups when lignin modifications need to take place (Stewart 2008; Doherty et al. 2011; Li and Ragauskas 2012).

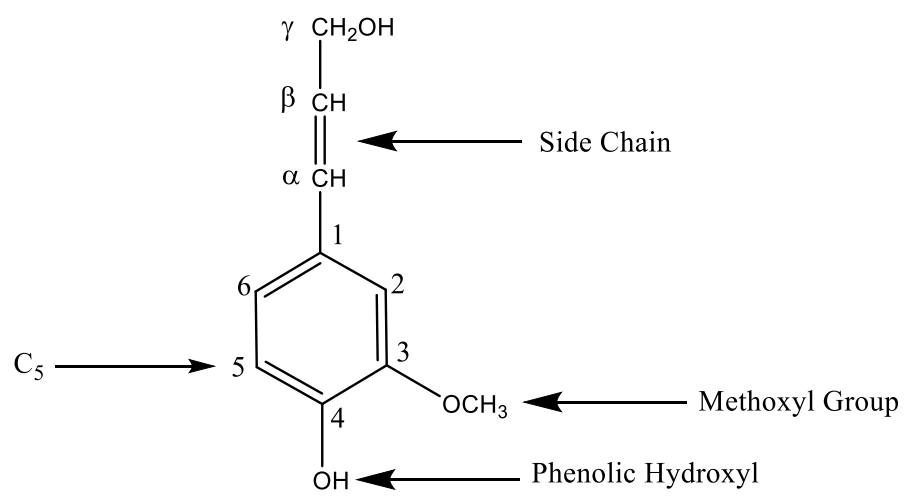

Fig. 3. Lignin monomer unit within lignin 
Two factors that limit the further utilization of lignin in phenolic foams include the low reactivity and high molecular weight. Compared with phenol, lignin possesses fewer reactive sites for formaldehyde, which leads to fewer crosslinks formed in the foams, thus lowering the mechanical properties of the products. The reactivity can be increased either by introducing new reactive groups or by creating reactive sites on the original structure. The high molecular weight of lignin makes it difficult to reach an $80 \%$ solid content. Popular modification methods to improve the utilization of phenolic compounds include phenolation, hydroxymethylation, demethylation, and depolymerized hydrolysis lignin (Li and Ragauskas 2012; Yang et al. 2014a).

\section{Phenolation}

One of the most promising methods for lignin modification is phenolation. This method is an option for improving the reactivity of lignin by increasing the amount of phenolic hydroxyl groups and decreasing the molecular weight (Jiang et al. 2018). Different methods have been proposed for lignin phenolation. In phenolation reactions, a phenol is attached to the lignin structure. The first step is the protonation of the benzyl hydroxyl group, which is followed by the dehydration of $\alpha$-carbon. Phenol undergoes electrophilic aromatic substitution with the carbonium ion, which allows for the formation of phenol-lignin condensation products. Fragmentation takes place after the incorporation of an ortho- or para-phenyl compound to substitute the $\alpha$-hydroxyl groups in the propyl side chains (Nada et al. 1987). Some side reactions can also occur depending on the reaction (processing) conditions (Alonso et al. 2005; Laurichesse and Avérous 2014).

Newer studies have proposed that lignin substructures $(\beta-\mathrm{O}-4,, \beta-5$ ' $/ \alpha-\mathrm{O}-4$ ', $\beta-\beta$ ', $\alpha$-carbonyl, etc.) react, which increases the amount of phenolic $\mathrm{OH}$ present in the structure. In addition to considering ortho and para positions for lignin phenolation, Jiang et al. (2018) suggested the presence of more substructures (Fig. 4) because of the elimination of formaldehyde from $\gamma$-carbon.

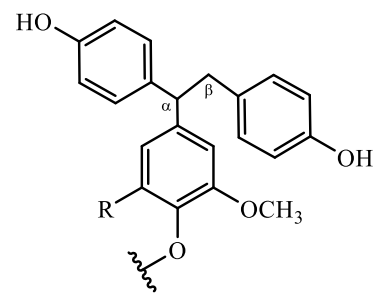

1. $\mathrm{R}=\mathrm{H}$ or $\mathrm{OCH}_{3}$

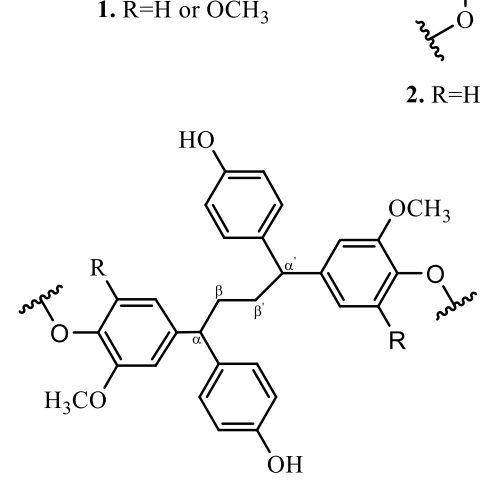

6. $\mathrm{R}=\mathrm{H}$ or $\mathrm{OCH}_{3}$

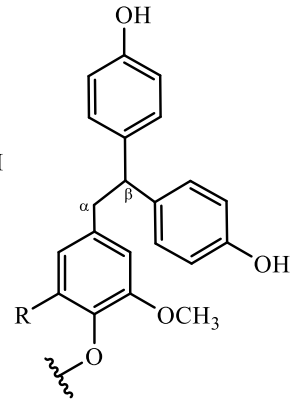

$\mathrm{R}=\mathrm{H}$ or $\mathrm{OCH}_{3}$<smiles>COc1ccc(C(CO)C(c2ccccc2O)c2ccccc2O)cc1OC</smiles>

3

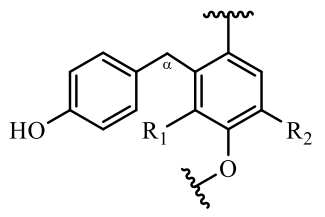

9. $\mathrm{R}_{1}=\mathrm{H}, \mathrm{R}_{2}=\mathrm{OCH}_{3}$ 10. $\mathrm{R}_{1}=\mathrm{OCH}_{3}, \mathrm{R}_{2}=\mathrm{C}$ or $\mathrm{OCH}_{3}$

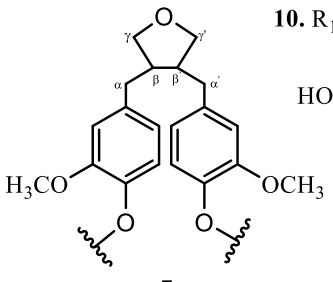

7.
8.<smiles>CCOc1c(Cc2ccc(O)cc2)cc(C)cc1OC</smiles>

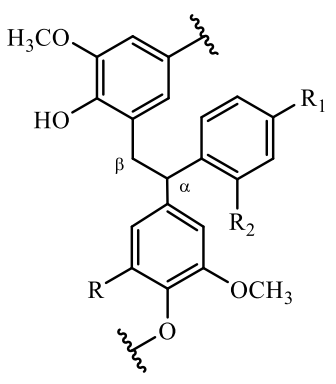

4. $\mathrm{R}_{1}=\mathrm{H}, \mathrm{R}_{2}=\mathrm{OH}$ 5. $\mathrm{R}_{1}=\mathrm{OH}, \mathrm{R}_{2}=\mathrm{H}$
Fig. 4. Plausible substructures present in phenolated lignin; adapted from Jiang et al. (2018) 
In addition to the effect of the reaction conditions, the phenolation of lignin can be affected by the lignin isolation process, which is found on the natural form of lignin (Raquez et al. 2010). Different types of lignin can be used for phenolation. The effect of phenolation on lignins (hardwood, softwood, and annual plants) and pulping methods (organosolv, kraft, soda, sulfite, and hydrolysis) have been studied (Podschun et al. 2015). Phenolation has also been studied with other lignin types, such as ammonium lignosulfonates; the conditions that must be employed to achieve phenolation of this lignin type without compromising the mechanical properties include a high temperature $\left(120^{\circ} \mathrm{C}\right)$, long reaction time (160 min), and low lignosulfonate content (30\%) (Alonso et al. 2005).

As well as increasing the number of reactive sites with the presence of a higher number of p-hydroxyphenyl units, it is known that phenolation can decrease the molecular weight and polydispersity of lignin, which are more pronounced at higher temperatures and longer reaction times. This phenomenon is a result of lignin fragmentation during the phenolation process (Alonso et al. 2005). These properties make lignin attractive for different applications. In foams, lignin phenolation has potential value, but the main restriction of lignin use in foams is the gelation of resol during evaporation to an $80 \%$ solid content. However, controlled phenolation processing conditions can lead to low molecular weight lignin, which decreases the viscosity of the resol and avoids resol gelation (Alonso et al. 2005).

Phenolation is performed to improve the lignin reactivity towards formaldehyde by attaching phenol to the lignin structure, as well as by lowering the molecular weight by cleavage of ether bonds, such as $\beta-\mathrm{O}-4$. Phenolation can be performed either in an acidic medium or under alkaline conditions. The synthesis of phenolated lignin under alkaline conditions has been reported by Yang et al. (2014b). In their work, four types of technical lignins were phenolated, and their structure and functional groups were compared. According to their report, no major differences in the $\beta-O-4$ and $\beta-\beta$ amounts were seen, while the H-unit content increased after phenolation. However, it was not clearly established whether the phenol residues were covalently bonded or if the residual phenol was physically attached to the lignin.

\section{Hydroxymethylation}

The objective of hydroxymethylation is to increase the reactive sites by introducing hydroxymethyl $\left(-\mathrm{CH}_{2} \mathrm{OH}\right)$ groups to lignin macromolecules. The reaction takes place following electrophilic aromatic substitution (Sen et al. 2015). Hydroxymethylation can be carried out by mixing lignin with formaldehyde at a specific ratio and reacting at $75{ }^{\circ} \mathrm{C}$ to $90{ }^{\circ} \mathrm{C}$ in an alkaline medium (Benar et al. 1999; Gonçalves and Benar 2001; Malutan et al. 2008). The reaction pathway for the introduction of hydroxymethyl groups to the lignin structure is shown in Fig. 5.

During the characterization of hydroxymethylated lignin, ether bonds are also cleaved, which leads to a lower molecular weight and higher flexibility. Because of less blocking of the C5 position, softwood is a better starting material for hydroxymethylation compared with hardwood (Zhao et al. 1994).

Despite showing potential phenol replacement and similar properties to phenolic products, hydroxymethylation has not been used on an industrial scale. The main restriction of hydroxymethylation for lignin modification is the occurrence of side reactions in which formaldehyde reacts with itself and aliphatic methylol groups are introduce in lignin side chains (Hu et al. 2011). New laws concerning formaldehyde emissions from wood products have limited the use of hydroxymethylation in adhesives and resins, which have major 
applications in wood products (U.S. EPA 2017). Consequently, the application of this method in phenolic foams has also been limited because the potential uses include building insulation and the standards for free formaldehyde emissions are rigorously enforced.

1)

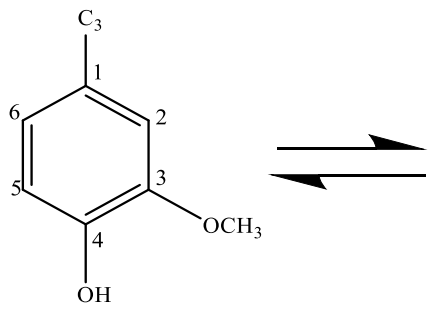

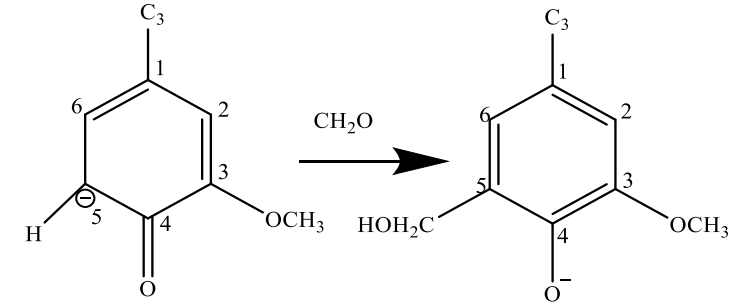

2)

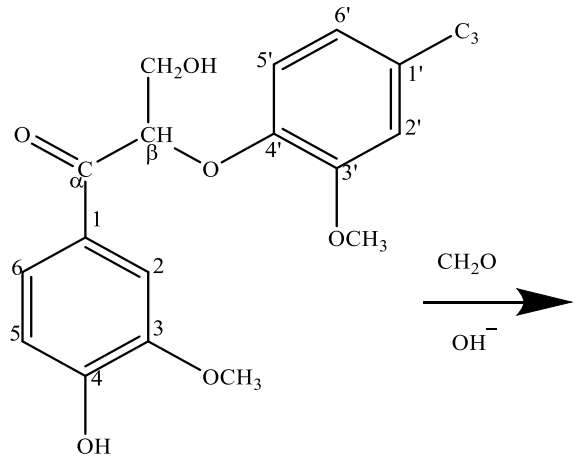

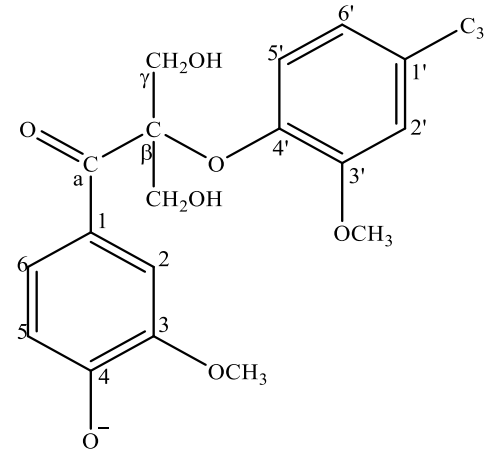

Fig. 5. Reaction pathway of the hydroxymethylation of lignin; adapted from Benar et al. (1999)

\section{Demethylation}

Demethylation converts methoxyl groups into hydroxyl groups. In raw lignin, the ortho positions are blocked by methoxyl groups, which are not available to react with formaldehyde. Demethylation improves the reactivity by making reactive sites more available (Hu et al. 2011). Lignin demethylation can be performed by biological means or under acidic or alkaline conditions. The primary products include vanillin, syringaldehyde, and other aromatic aldehydes, with yields ranging from $5 \%$ to $10 \%$ at an industrial scale (Kaszonyi et al. 1989; Li et al. 2016).

Because side reactions may occur frequently, the demethylation yield is low. Different options to make this process more cost-effective have been studied. Some of these options include sodium periodate (Marton and Adler 1963), iodocyclohexane with dimethylformamide (Fig. 6) (Song et al. 2016), and Lewis acid catalyzed demethylation (Chung and Washburn 2012). For less energy input, enzymatic oxidation is a wellestablished method. Oxidized lignin production using the white-rot fungus Bjerkandera adusta has been studied with reported aldehydic monomer yields of approximately $40 \%$ (Nakamura et al. 1999). Despite the low yield, demethylation can increase the amount of hydroxyl groups by $28 \%$ (Chung and Washburn 2012), which leads to an improved reactivity towards formaldehyde.

Similar to other modification methods, demethylation is highly dependent upon the lignin type. In this case, the presence of guaiacyl and syringyl propane units is essential to achieve lignin demethylation because these two lignin precursors contain methoxyl groups in their structure. The products obtained can be used as oxidized phenols, chelating material, or controlled-release matrices. The applications may be related to different 
processes, depending on the functional groups. Because of its low yield at an industrial scale, demethylation is not commonly used.

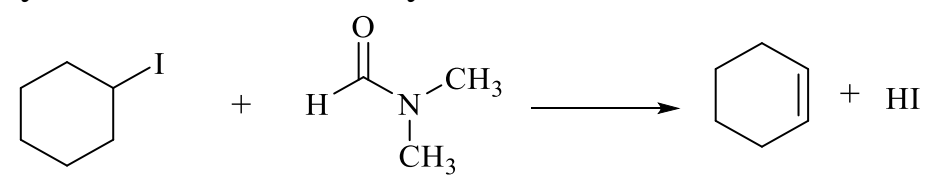

Iodocyclohexane Dimethylformamide Cyclohexene

(DMF)

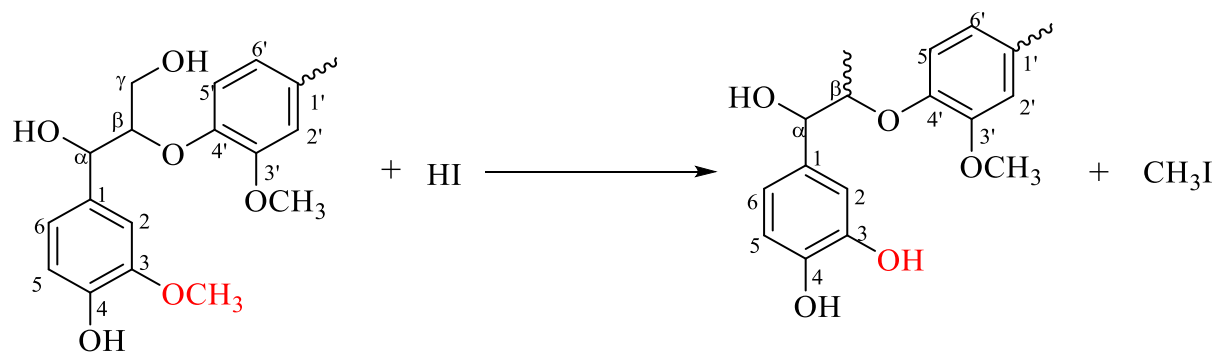

Lignin

Fig. 6. Chemical pathway for lignin demethylation

\section{Depolymerized Hydrolysis Lignin}

Hydrolysis is a process in which water is used to break down molecules. For lignin, hydrolysis can be done using either an acidic or alkaline medium (Pandey and Kim 2011). Hydrolytic treatments yield lower molecular weight structures by cleaving lignin bonds (Thring 1994).

In an acidic medium, lignin is reacted with a strong acid and catalyst, which demethylates the phenyl-propane unit and results in ortho substitution by hydroxyl groups. Hydrolyzed lignin is placed under a high temperature to cleave the ether bonds of the phenyl-propane units present in the lignin structure, which results in more reactive monomeric units. In contrast, an alkaline medium uses - $\mathrm{OH}$ groups as a primary catalytic agent, which is commonly used in pulping reactions for breaking lignin apart (Li et al. 2017). Hydroxyl groups present in the medium will attack different lignin bonds and yield different ether bonds that can be easily cleaved by other treatments (Thring 1994). A general pathway of lignin hydrolysis is shown in Fig. 7.<smiles>CC(O)c1ccc(OC(C)C(O)c2ccc(O)c(O)c2)c(O)c1</smiles>

Hydrolyzed lignin (HL)<smiles>CCCC(O)c1ccc(O)c(O)c1</smiles><smiles>CSCC(O)c1ccc(O)c(O)c1</smiles>

Fig. 7. Depolymerized hydrolysis lignin pathway 
After either an acidic or alkaline treatment, lignin is prone to degradation, which yields new phenolic hydroxyl-containing units with low molecular weights. In an alkaline medium, lignin degradation products can be useful in condensation reactions that result in phenolic products. Even though a large number of phenolic compounds are produced in acidic media, this process is usually performed in non-aqueous media, and the product must be separated from an organic solvent before it can be used (El Mansouri and Salvadó 2006).

The potential applications of this modification for use in phenolic foams rely on the fact that low molecular weight lignin can avoid gelation stages during solvent and water evaporation to obtain an $80 \%$ solid content for foam formation. Likewise, by avoiding gel formation, a higher amount of lignin can be included in the material without compromising the mechanical properties.

\section{COMPARISON OF DIFFERENT MODIFICATION METHODS}

Lignin structural modification is done with the intention of achieving a higher phenol substitution in the foam formula, as well as better mechanical and thermal properties. There is no clear choice when choosing a modification method. The modification method, as well as the processing parameters, depend on the lignin type and characteristics.

Phenolation has been shown to be one of the most promising modification methods. It works to increase the reactivity by introducing reactive sites and lowers the molecular weight and polydispersity. Theoretically, phenolation works for all types of lignin with different amounts of incorporated phenol. The degree of phenolation depends on the lignin type, functional groups, and lignin structure, as well as the phenolation process. Podschun et al. (2015) investigated the structure-function relationships and proposed a correlation between the degree of phenolation and aliphatic hydroxyl groups. However, the relationship might have been arbitrary because the degree of phenolation also correlated with the amount of other reactive sites, such as $\beta-\mathrm{O}-4$ and carbonyl groups.

Table 2 shows the common linkages in softwood and hardwood lignin (Chakar and Ragauskas 2004; Chattopadhyay and Raju 2007; Zakzeski et al. 2010). The given numbers were calculated based on the original lignin in wheat straw, corncob, bagasse, agricultural residues, wood, switchgrass, corn stover, straw, and hybrid poplar without any chemical or physical pretreatment. The functional groups and linkages of the available technical lignins vary with the pretreatment process. For example, depending on the processing conditions, $\beta$-O-4 linkages in softwood lignin decreased to $5 \%$ to $7 \%$ after kraft pulping (An et al. 2015; Constant et al. 2016). The phenolation efficiency for organosolv lignin is generally higher than kraft lignin, as is shown by the amount of incorporated $p$-hydroxyl in Fig. 5.

Unlike phenolation, which works for almost all kinds of lignin, hydroxymethylation is restricted because it requires unblocked C3 and C5 positions on the original lignin structure. As is listed in Table 2, the number of activated sites (free C3 and C5 positions) in softwood lignin is higher than in hardwood and non-woody lignin. Therefore, hydroxymethylation works better for softwood lignins than other lignin types. The effects of hydroxymethylation on different lignin types are summarized in Table 3. Also, the efficiency of hydroxymethylation is limited because of unwanted reactions on the side chain of lignin (Fig. 6) and the occurrence of undesirable Cannizzarro reactions of the formaldehyde (Swain et al. 1979; Malutan et al. 2008; Todorciuc et al. 2009). 
Table 2. Common Linkages in Softwood and Hardwood Lignin

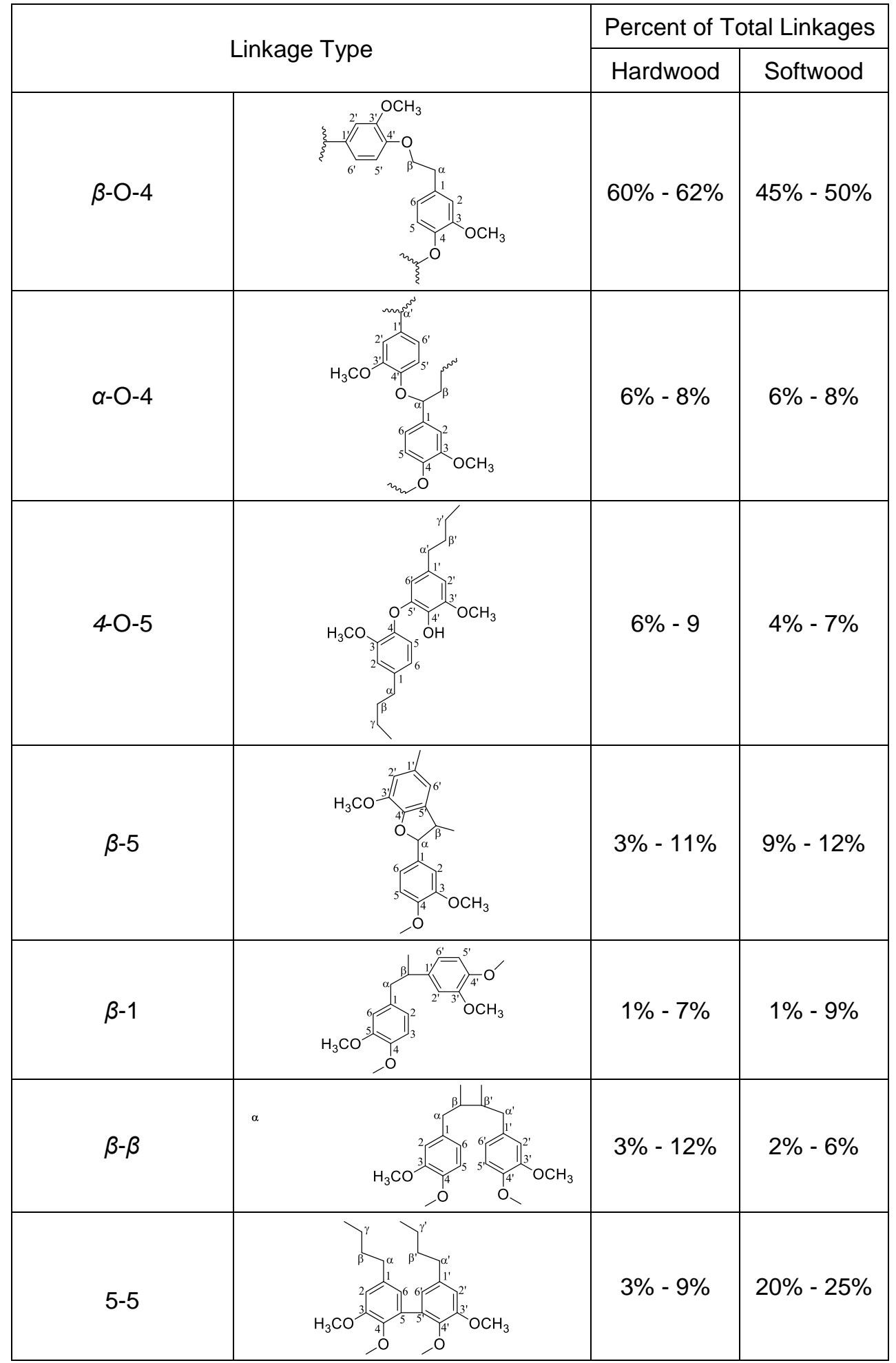

Chakar and Ragauskas (2004); Chattopadhyay and Raju (2007); Zakzeski et al. (2010)

Another disadvantage compared with phenolation is that hydroxymethylation barely changes the lignin structure. As is shown in Fig. 5, the main reactions that occur during hydroxymethylation are the incorporation of hydroxymethyl groups onto the open 
C5 positions and lignin side chains. Hydroxymethylation shows no remarkable modification to the molecular weight and molecular weight distribution of the original lignin. When substituting phenol with lignin in phenolic foams, one of the biggest challenges is the difficulty in reaching an $80 \%$ solid content because of the higher molecular weight. Thus, although hydroxymethylation improves the reactivity of lignin, it is not as sufficient for modifying the lignin structure for better foam processing. Hydroxymethylation may be more suitable for lignins with lower molecular weights or it could be combined with solvent fractionation for better utilization in phenolic foam production.

Table 3. Functional Groups of Various Lignin Samples and Hydroxymethylated Derivatives

\begin{tabular}{|c|c|c|c|c|c|}
\hline Sample & Resource & $\begin{array}{c}\text { Total -OH } \\
\text { Groups }\end{array}$ & $\begin{array}{l}\text { Ar-OH } \\
\text { Groups }\end{array}$ & $\begin{array}{c}\text { Incorporated } \\
-\mathrm{OH}\end{array}$ & S/G Ratio \\
\hline Wheat straw lignin & \multirow{2}{*}{ Non-woody } & 1.06 & 0.93 & - & 0.82 \\
\hline Wheat straw lignin- $\mathrm{H}$ & & 1.16 & 0.98 & 0.10 & 0.97 \\
\hline Sarkanda grass lignin & \multirow{2}{*}{ Non-woody } & 1.05 & 0.91 & - & 0.82 \\
\hline Sarkanda grass lignin- $\mathrm{H}$ & & 1.14 & 0.95 & 0.09 & 0.85 \\
\hline Kraft lignin & \multirow{2}{*}{ Softwood } & 1.30 & 0.58 & - & 0.37 \\
\hline Kraft lignin- $\mathrm{H}$ & & 1.65 & 0.57 & 0.35 & 0.46 \\
\hline
\end{tabular}

-OH groups: per $\mathrm{C} 9$ groups based on proton nuclear magnetic resonance ( ${ }^{1} \mathrm{H}$ NMR); Zhao et al. (1994); Tejado et al. (2007); Malutan et al. (2008)

Although demethylation improves the reactivity of lignin towards formaldehyde, it does not help with modifying the lignin structure and molecular weight. For lignin demethylation, the disadvantages mainly lie in the expensive reagents and catalysts, low yields, and the residual heterogeneous structure of the demethylated lignin. Because of these disadvantages, only a limited body of work is available on the utilization of demethylated lignin in foaming products.

Lignin hydrolysis can be conducted under either acidic or alkaline conditions, as well as in a solvent system with a catalyst (Matsushita et al. 2008; Nenkova et al. 2008; Yuan et al. 2010). Matsushita et al. (2008) studied the acid hydrolytic degradation of lignin for the synthesis of ionic exchange resins. Because of the cleavage of various linkages, such as $\beta$-ether and $\alpha$-ether bonds, the molecular weight of lignin decreases and the hydroxyl groups increase after acid hydrolytic degradation. The main disadvantages of hydrolysis in an acidic medium lie in the unfavorable re-polymerization of the degraded lignin products, which generates repolymerized lignin with a higher molecular weight, and the challenge of waste treatment because of the use of acid. The hydrolysis of lignin under alkaline conditions has also been investigated. Similar to acid hydrolytic degradation, there is competition between de-polymerization and re-polymerization (Nenkova et al. 2008). In general, the cost of the hydrolytic degradation of lignin is higher than for phenolation and demethylation because of the severity of the reaction conditions (higher temperature or pressure) and the need for expensive catalysts in some cases. Therefore, this method may not be economically viable.

The modification described in the section above has encouraging results for improving some properties of phenolic foams; however, the amount of lignin used to replace phenol in the mixture is high and it is still a challenge to achieve the total replacement of phenol. As was demonstrated in the current review for the choice between 
the direct use and indirect use of lignin, there is not a remarkable improvement in the substitution rate. New methods are required to obtain a higher amount of lignin in the matrix.

Table 4. Functional Groups and Activated Sites in Various Technical Lignins

\begin{tabular}{|c|c|c|c|c|c|c|}
\hline \multicolumn{2}{|c|}{ Resource } & UV-spec. & \multicolumn{2}{c|}{${ }^{1} \mathrm{H}$ NMR } & \multicolumn{2}{c|}{ Activated Sites } \\
\cline { 2 - 7 } & $\begin{array}{c}\mathrm{OH} \\
\text { Phenolic }\end{array}$ & $\begin{array}{c}\mathrm{OH} \\
\text { Phenolic }\end{array}$ & $\begin{array}{c}\mathrm{OH} \\
\text { Aliphatic }\end{array}$ & UV-spec. & $\begin{array}{c}\text { Mannich } \\
\text { Reactivity }\end{array}$ \\
\hline Kraft lignin & Softwood & 4.50 & 4.10 & 10.09 & 0.32 & 0.40 \\
\hline $\begin{array}{c}\text { Soda- } \\
\text { Anthraquionone } \\
\text { lignin }\end{array}$ & Softwood & 4.40 & 4.50 & 3.10 & 0.36 & 0.36 \\
\hline $\begin{array}{c}\text { Organosolv } \\
\text { lignin }\end{array}$ & $\begin{array}{c}\text { Non- } \\
\text { woody }\end{array}$ & 2.66 & 3.33 & 3.50 & 0.16 & 0.21 \\
\hline $\begin{array}{c}\text { Ethanol } \\
\text { process lignin }\end{array}$ & Hardwood & 2.30 & 2.65 & 4.73 & 0.23 & 0.28 \\
\hline Lignosulfonate & Softwood & 2.00 & NA & NA & 0.23 & 0.24 \\
\hline
\end{tabular}

Functional groups in \% (w/w) based on the dry matter; activated sites - free C3 and C5 per C9 unit; NA: not analyzed; UV-spec.: UV-spectroscopy; El Mansouri and Salvadó (2006)

\section{UTILIZATION OF LIGNIN IN PHENOLIC FOAMS}

\section{Direct Utilization of Lignin in Phenolic Foams}

The direct use of lignin in phenolic foams without previous modification has not been adequately studied. Because lignin has a low reactivity, the substitution rate of phenol in foams is low and an increase in the lignin amount affects the mechanical performance of the foams. Additionally, a high molecular weight of raw lignin leads to the gelation of the resol during evaporation when a higher substitution of phenol is desired. When the amount of lignin is increased, the mechanical properties, such as the flexural and compressive strengths, are negatively affected. However, in contrast to the mechanical properties, the thermal performance of foams is improved with the addition of lignin (Zhuang et al. 2011).

As was discussed in the Lignin Modification section, the biological source of lignin (hardwood, softwood, or annual plants) has an impact on the final properties of the products it is used to generate. Different lignin types have been studied for application in phenolic foams. For example, lignin from steam-exploded corn stalk has been used for lignin foams as a concentrated liquor from alkali extraction. The addition of lignin in foams has resulted in a higher apparent density and compression strength compared with that of conventional phenolic foams. However, studies have shown that increased substitution rates do not result in a major improvement in the thermal conductivity and fire-retardant properties. In related works, the achieved substitution rate has been up to $30 \%$. For the morphological properties, lignin-based phenolic foams have shown similarities in pore size and distribution with phenolic foams (Wang and Chen 2014).

Lignin derivatives have also been used in phenolic foams. For example, lignin nanoparticles have been used as a filler and achieved an $8.5 \%$ substitution rate for optimum mechanical properties. Although the substitution rate is comparatively low, one of the benefits of lignin nanoparticles is the reduction in the blowing agent amount without 
affecting the mechanical performance (Del Saz-Orozco et al. 2012). Table 5 shows some properties of phenolic foams using different reinforcements, including lignin nanoparticles.

Table 5. Compressive Mechanical Properties and Apparent Density of Several Reinforced Phenolic Foams

\begin{tabular}{|c|c|c|c|c|c|c|c|}
\hline Foam & Reinforcement & Nt.\%) & $\rho\left(\mathrm{kg} / \mathrm{m}^{3}\right)^{\mathrm{a}}$ & $E(I$ & $\mathrm{Pa})^{\mathrm{b}}$ & $\sigma_{c}(I$ & $\mathrm{Pa})^{\mathrm{c}}$ \\
\hline \multirow{3}{*}{ Phenolic } & Unreinforced & 0 & 120 & 14.7 & $(100)$ & 0.474 & (100) \\
\hline & $\begin{array}{c}\text { Lignin } \\
\text { nanoparticles }\end{array}$ & 8.5 & - & 18.9 & $(128)$ & 0.824 & (174) \\
\hline & Wood flour & 1.5 & - & 19.1 & $(130)$ & 0.731 & (154) \\
\hline
\end{tabular}

\section{Modified Lignin in Phenolic Foams}

To further increase the lignin substitution rate in foams while maintaining acceptable mechanical and thermal properties, research has focused on modifying the lignin structure (Yang et al. 2014a). However, most of the research has been done with adhesives and only a few works relate to phenolic foams (Vázquez et al. 1997; Mankar et al. 2012). In general, the works done with modified lignin phenolic foams have shown improved thermal properties. Conventional phenolic foams have a degradation temperature of approximately $260{ }^{\circ} \mathrm{C}$, while modified lignin phenolic foams have a degradation temperature of $400{ }^{\circ} \mathrm{C}$ or higher (de Carvalho and Frollini 2002; Hu et al. 2012; Li et al. 2017). More information on the flammability, thermal conductivity, and fire and smoke stability needs to be obtained. Despite the importance of thermal conductivity in phenolic foams for insulation applications, only one study has discussed this property. For ligninmodified phenolic foams, the reported thermal conductivity is $0.04 \mathrm{~W} / \mathrm{m} \cdot \mathrm{K}$ ( Li et al. 2017). For reference, the thermal conductivity values range from $0.019 \mathrm{~W} / \mathrm{m} \cdot \mathrm{K}$ to $0.046 \mathrm{~W} / \mathrm{m} \cdot \mathrm{K}$ for typical insulants (European Commission 2010).

The mechanical performances of foams are related to the processing conditions, such as the phenol to formaldehyde ratio, temperature, reaction time, etc., and the foam properties, such as the density. Even though a broad range of variables and parameters can influence these properties, a reference value of approximately $0.18 \mathrm{MPa}$ (Schroer et al. 2012) has been established for the compressive strength. As can be seen in Table 6, the compressive strength of modified-lignin phenolic foams ranges from $0.09 \mathrm{MPa}$ to $10 \mathrm{MPa}$. For the elastic modulus of lignin phenolic foams, values ranging from $2.16 \mathrm{MPa}$ to 12.8 MPa have been reported (de Carvalho and Frollini 2002; Lee et al. 2002; de Carvalho et al. 2003; Hu et al. 2012, 2013; Li et al. 2017). Even when it is a wide range, these values are comparable to standard values for phenolic foams (Table 6). A deeper study needs to be done into the mechanical properties of lignin phenolic foams.

Of the properties discussed above, density deserves more attention. One of the advantages of conventional phenolic foams is their lightweight structure. Density values for modified lignin foams range from $28 \mathrm{~kg} / \mathrm{m}^{3}$ to $66 \mathrm{~kg} / \mathrm{m}^{3}$, which falls in the range of standard density values for conventional foams $\left(25 \mathrm{~kg} / \mathrm{m}^{3}\right.$ to $\left.60 \mathrm{~kg} / \mathrm{m}^{3}\right)$ (BS EN 131662010). However, as can be seen in Table 6, the density for some modified processes is high. For these cases, the presence of lignin increases the resol molecular weight, which makes the attainment of an $80 \%$ solid content for foam formation harder to achieve by hindering the evaporation of the blowing agent during the foaming process (Li et al. 2017). 
Table 6. Lignin Modifications for Use in Phenolic Foams and Lignin-modified Phenolic Foam Properties

\begin{tabular}{|c|c|c|c|c|c|c|c|c|}
\hline \multirow[b]{2}{*}{ Modification } & \multirow{2}{*}{$\begin{array}{l}\text { Type of Lignin } \\
\text { (Source) }\end{array}$} & \multirow{2}{*}{$\begin{array}{l}\text { Substitution } \\
\text { Rate }\end{array}$} & \multicolumn{5}{|c|}{ Property } & \multirow[b]{2}{*}{ Reference } \\
\hline & & & $\begin{array}{c}\text { Thermal } \\
\text { Decomposition }\end{array}$ & $\begin{array}{l}\text { Compression } \\
\text { Strength }\end{array}$ & $\begin{array}{l}\text { Elastic } \\
\text { Modulus }\end{array}$ & Density & $\begin{array}{c}\text { Thermal } \\
\text { Conductivity }\end{array}$ & \\
\hline $\begin{array}{l}\text { Phenolic foam } \\
\text { (standard) }\end{array}$ & None & $0 \%$ & NR & $\begin{array}{l}0.10 \mathrm{MPa}- \\
0.12 \mathrm{MPa}\end{array}$ & NR & $\begin{array}{l}32 \mathrm{~kg} / \mathrm{m}^{3}- \\
120 \mathrm{~kg} / \mathrm{m}^{3}\end{array}$ & $\begin{array}{c}0.021 \mathrm{~W} / \mathrm{m} \cdot \mathrm{K} \\
-0.045 \\
\mathrm{~W} / \mathrm{m} \cdot \mathrm{K}\end{array}$ & $\begin{array}{l}\text { ASTM } \\
\text { C1126 } \\
(2015) \\
\end{array}$ \\
\hline \multirow[b]{2}{*}{ Phenolation } & Lignosulfonate & $20 \%$ & $443^{\circ} \mathrm{C}$ & $0.15 \mathrm{MPa}$ & NR & $28.55 \mathrm{~kg} / \mathrm{m}^{3}$ & NR & $\begin{array}{l}\text { Hu et al. } \\
\text { (2012) }\end{array}$ \\
\hline & $\begin{array}{c}\text { Liquefied } \\
\text { lignocellulosic } \\
\text { biomass }\end{array}$ & NR & NR & $\begin{array}{c}0.09 \mathrm{MPa}- \\
0.21 \mathrm{MPa}(10 \% \\
\text { Strain) }\end{array}$ & $\begin{array}{l}\text { 3.4 MPa - } \\
12.8 \mathrm{MPa}\end{array}$ & $\begin{array}{c}32 \mathrm{~kg} / \mathrm{m}^{3}- \\
66 \mathrm{~kg} / \mathrm{m}^{3}\end{array}$ & NR & $\begin{array}{l}\text { Lee et al. } \\
\text { (2002) }\end{array}$ \\
\hline \multirow[t]{2}{*}{ Hydroxymethylation } & $\begin{array}{c}\text { Organosolv } \\
\text { (Sugarcane } \\
\text { Bagasse) }\end{array}$ & $25 \%$ & $300^{\circ} \mathrm{C}-400^{\circ} \mathrm{C}$ & NR & NR & $450 \mathrm{~kg} / \mathrm{m}^{3}$ & NR & $\begin{array}{c}\text { de } \\
\text { Carvalho } \\
\text { and } \\
\text { Frollini } \\
\text { (2002) }\end{array}$ \\
\hline & $\begin{array}{c}\text { Organosolv } \\
\text { (Sugarcane } \\
\text { Bagasse) }\end{array}$ & $25 \%$ & NR & $\begin{array}{c}10 \mathrm{MPa} \\
(\text { ASTM-D- } \\
1621,2016)\end{array}$ & NR & $\begin{array}{l}250 \mathrm{~kg} / \mathrm{m}^{3}- \\
450 \mathrm{~kg} / \mathrm{m}^{3}\end{array}$ & NR & $\begin{array}{c}\text { de } \\
\text { Carvalho } \\
\text { et al. } \\
(2003)\end{array}$ \\
\hline Oxidation & Lignosulfonate & $30 \%$ & NR & $0.15 \mathrm{MPa}$ & NR & $\begin{array}{l}50 \mathrm{~kg} / \mathrm{m}^{3}- \\
55 \mathrm{~kg} / \mathrm{m}^{3}\end{array}$ & NR & $\begin{array}{c}\text { Hu et al. } \\
\text { (2013) }\end{array}$ \\
\hline $\begin{array}{c}\text { Depolymerized } \\
\text { Hydrolysis }\end{array}$ & $\begin{array}{l}\text { Hydrolysis lignin } \\
\text { (Hardwood) }\end{array}$ & $30 \%-50 \%$ & $450^{\circ} \mathrm{C}$ & $\begin{array}{c}0.15 \mathrm{MPa}- \\
0.41 \mathrm{MPa}(10 \% \\
\text { Strain) }\end{array}$ & $\begin{array}{c}2.16 \mathrm{MPa}- \\
7.56 \mathrm{MPa}\end{array}$ & $\begin{array}{l}40 \mathrm{~kg} / \mathrm{m}^{3}- \\
108 \mathrm{~kg} / \mathrm{m}^{3}\end{array}$ & $\begin{array}{l}0.04 \mathrm{~W} / \mathrm{m} \cdot \mathrm{K}- \\
0.033 \mathrm{~W} / \mathrm{m} \cdot \mathrm{K}\end{array}$ & $\begin{array}{l}\text { Li et al. } \\
\text { (2017) }\end{array}$ \\
\hline
\end{tabular}

NR: not reported 
In addition to the importance of having a full characterization of the final product, a full description of lignin is important to understand the advantages and disadvantages of each modification method. As was previously mentioned, the effectiveness of the lignin modification methods is dependent on the biological source and processing conditions. Additionally, the lignin molecular weight can have a large impact on the final properties of the foam. Modification needs to be done not only to increase the reactivity, but also to lower the molecular weight of the structure to make the foaming process more cost effective by decreasing the evaporation time to achieve an $80 \%$ solid content and increasing the amount of lignin in the material.

The results in Table 6 show the potential of phenolation and depolymerized hydrolysis lignin. These two processes can reduce the lignin molecular weight and increase the reactivity on the lignin molecule by making more sites that are reactive and available for formaldehyde to attach and crosslink. In contrast, hydroxymethylation can improve the reactivity with formaldehyde, but it also increases the molecular weight. This leads to highdensity foams, which are undesirable for final product application because the formed foams are more brittle, which leads to a poor mechanical performance.

Finally, additional work to characterize better lignin-phenolic foams is important to have a better idea of the potential applications. For example, it is also important to consider corrosion testing. One of the biggest problems of conventional phenolic foams is that they can accelerate iron and steel corrosion in low $\mathrm{pH}$ environments, which is a big issue if the application of pipe insulation is considered for example (Schroer et al. 2012). Additionally, the potential presence of residual formaldehyde in foams and water absorption need to be evaluated. All of this is necessary to better understand the potential uses and scale up process of this product.

\section{CONCLUSIONS}

Of the lignin modifications studied, phenolation is the most common modification for incorporating lignin into phenolic compounds and results in a remarkable improvement in the thermal properties. However, the degree of phenolation of lignin is as an important issue because the effectiveness of this process is affected by the lignin type and process. This is because the reactive sites available vary for different lignin types.

For lignin-based phenolic foams, little work has been published, which opens the opportunity to investigate higher substitution rates and acceptable mechanical properties. This review summarized the reported works and proposed modification methods for ligninbased phenolic foams. While depolymerized lignin-based phenolic foams with a substitution rate of up to $50 \%$ have been successfully prepared in the literature, this method still faces a wide range of challenges ahead, such as the commercial availability of depolymerized lignin. Furthermore, the results presented herein are still controversial and have not performed scale-up testing to verify the processability and stability. Therefore, the development of lignin-based phenolic foams with a well-defined structure, acceptable mechanical properties, and thermal properties is still a great challenge. In contrast, various types and characteristics of lignin may lead to various formulations and processes to obtain optimum properties, and there is no existing literature concerning this. Therefore, the optimum foaming process, including the blowing agent levels, catalyst loading, and curing temperature, needs to be further investigated. 


\section{REFERENCES CITED}

Alonso, M. V., Oliet, M., Rodríguez, F., García, J., Gilarranz, M. A., and Rodríguez, J. J. (2005). "Modification of ammonium lignosulfonate by phenolation for use in phenolic resins," Bioresource Technol. 96(9), 1013-1018. DOI:

10.1016/j.biortech.2004.09.009

An, Y.-X., Li, N., Wu, H., Lou, W.-Y., and Zong, M.-H. (2015). "Changes in the structure and the thermal properties of kraft lignin during its dissolution in cholinium ionic liquids," ACS Sustain. Chem. Eng. 3(11), 2951-2958. DOI:

10.1021/acssuschemeng.5b00915

Araújo, J. D. P., Grande, C. A., and Rodrigues, A. E. (2010). "Vanillin production from lignin oxidation in a batch reactor," Chem. Eng. Res. Des. 88(8), 1024-1032. DOI: 10.1016/j.cherd.2010.01.021

Aseeva, R. M., Klempner, D., and Sendijarevíc, V. (2004). Handbook of Polymeric Foams and Foam Technology (2E), Hanser Publishers, Cincinatti, OH.

ASTM C1126 (2015). "Standard specification for faced or unfaced rigid cellular phenolic thermal insulation," ASTM International, West Conshohocken, PA.

ASTM D1621 (2016). "Standard test method for compressive properties of rigid cellular plastics," ASTM International, West Conshohocken, PA.

Benar, P., Gonçalves, A. R., Mandelli, D., and Schuchardt, U. (1999). "Eucalyptus organosolv lignins: Study of the hydroxymethylation and use in resols," Bioresource Technol. 68(1), 11-16. DOI: 10.1016/S0960-8524(98)00076-5

Boerjan, W., Ralph, J., and Baucher, M. (2003). "Lignin Biosynthesis," Annu. Rev. Plant Biol. 54, 519-546. DOI: 10.1146/annurev.arplant.54.031902.134938

Bremner, T., Zhor, J., Goyal, G. C., and Lora, J. H. (1997). "Lignin-based concrete admixtures," WO Patent No. 1997013733A1.

BS EN 13166 (2010). "Phenolic foam thermal insulation products for buildings and building services end use applications. Part 1 - Specification for phenolic foam (PF) products for use as thermal insulation for building wall cavities," British Standards Institute, London, UK.

Calvo-Flores, F. G., and Dobado, J. A. (2010). "Lignin as renewable raw material," ChemSusChem 3(11), 1227-1235. DOI: 10.1002/cssc.201000157

Chakar, F. S., and Ragauskas, A. J. (2004). "Review of current and future softwood kraft lignin process chemistry," Ind. Crop. Prod. 20(2), 131-141. DOI:

10.1016/j.indcrop.2004.04.016

Chattopadhyay, D. K., and Raju, K. V. S. N. (2007). "Structural engineering of polyurethane coatings for high performance applications," Prog. Polym. Sci. 32(3), 352-418. DOI: 10.1016/j.progpolymsci.2006.05.003

Chung, H., and Washburn, N. R. (2012). "Improved lignin polyurethane properties with Lewis acid treatment," ACS Appl. Mater. Inter. 4(6), 2840-2846. DOI: 10.1021/am300425x

Constant, S., Wienk, H. L. J., Frissen, A. E., de Peinder, P., Boelens, R., van Es, D. S., Grisel, R. J. H., Weckhuysen, B. M., Huijgen, W. J. J., Gosselink, R. J. A., et al. (2016). "New insights into the structure and composition of technical lignins: A comparative characterisation study," Green Chem. 18(9), 2651-2665. DOI: 10.1039/C5GC03043A

da Silva, E. A. B., Zabkova, M., Araújo, J. D., Cateto, C. A., Barreiro, M. F., Belgacem, M. N., and Rodrigues, A. E. (2009). "An integrated process to produce vanillin and 
lignin-based polyurethanes from kraft lignin," Chem. Eng. Res. Des. 87(9), 1276-

1292. DOI: 10.1016/j.cherd.2009.05.008

de Carvalho, G., and Frollini, E. (2002). "Lignin in phenolic closed cell foams: Thermal stability and apparent density," J. Macromol. Sci. A 39(7), 643-656. DOI:

10.1081/MA-120004509

de Carvalho, G., Pimenta, J. A., dos Santos, W. N., and Frollini, E. (2003). "Phenolic and lignophenolic closed cells foams: Thermal conductivity and other properties," Polym.-Plast. Technol. 42(4), 605-626. DOI: 10.1081/PPT-120023098

Del Saz-Orozco, B., Alonso, M. V., Oliet, M., Domínguez, J. C., Rojo, E., and Rodríguez, F. (2015). "Lignin particle- and wood flour-reinforced phenolic foams: Friability, thermal stability and effect of hygrothermal aging on mechanical properties and morphology," Compos. Part B-Eng. 80, 154-161. DOI: 10.1016/j.compositesb.2015.05.043

Del Saz-Orozco, B., Oliet, M., Alonso, M. V., Rojo, E., and Rodríguez, F. (2012). "Formulation optimization of unreinforced and lignin nanoparticle-reinforced phenolic foams using an analysis of variance approach," Compos. Sci. Technol. 72(6), 667-674. DOI: 10.1016/j.compscitech.2012.01.013

Doherty, W. O. S., Mousavioun, P., and Fellows, C. M. (2011). "Value-adding to cellulosic ethanol: Lignin polymers," Ind. Crop. Prod. 33(2), 259-276. DOI: 10.1016/j.indcrop.2010.10.022

Eaves, D. (2004). "Foam fundamentals," in: Handbook of Polymer Foams, Smithers Rapra Publishing, Shrewsbury, UK, pp. 1-8.

El Mansouri, N. E, and Salvadó, J. (2006). "Structural characterization of technical lignins for the production of adhesives: Application to lignosulfonate, kraft, sodaanthraquinone, organosolv and ethanol process lignins," Ind. Crop. Prod. 24(1), 8-16. DOI: 10.1016/j.indcrop.2005.10.002

European Commission (2010). Green Public Procurement - Thermal Insulation Technical Background Report, Brussels, Belgium.

Fache, M., Boutevin, B., and Caillol, S. (2016). "Vanillin production from lignin and its use as a renewable chemical," ACS Sustain. Chem. Eng. 4(1), 35-46. DOI: 10.1021/acssuschemeng.5b01344

Gardiziella, A., Pilato, L. A., and Knop, A. (2015). Phenolic Resins: Chemistry, Applications, Standardization, Safety and Ecology, Springer, Berlin, Germany.

Ghaffar, S. H., and Fan, M. (2014). "Lignin in straw and its applications as an adhesive," Int. J. Adhes. Adhes. 48, 92-101. DOI: 10.1016/j.ijadhadh.2013.09.001

Gibson, L. J., and Ashby, M. F. (1997). Cellular Solids Structure and Properties (Second Edition), Cambridge University Press, Cambridge, UK.

Gonçalves, A. R., and Benar, P. (2001). "Hydroxymethylation and oxidation of organosolv lignins and utilization of the products," Bioresource Technol. 79(2), 103111. DOI: $10.1016 / \mathrm{S} 0960-8524(01) 00056-6$

Grand View Research (2015). Lignin Market Analysis by Product (Ligno-sulphonates, Kraft Lignin, Organosolv Lignin, High Purity Lignin) by Application (Macromolecules, Aromatics) and Segment Forecasts To 2022, Grand View Research, San Francisco, CA.

Hu, L., Pan, H., Zhou, Y., and Zhang, M. (2011). “Methods to improve lignin's reactivity as a phenol substitute and as replacement for other phenolic compounds: A brief review," BioResources 6(3), 3515-3525. DOI: 10.15376/biores.6.3.3515-3525

Hu, L., Zhou, Y., Liu, R., Zhang, M., and Yang, X. (2013). "Synthesis of foaming resol 
resin modified with oxidatively degraded lignosulfonate," Ind. Crop. Prod. 44, 364366. DOI: 10.1016/j.indcrop.2012.11.034

Hu, L., Zhou, Y., Zhang, M., and Liu, R. (2012). "Characterization and properties of a lignosulfonate-based phenolic foam,” BioResources 7(1), 554-564. DOI: 10.15376/biores.7.1.554-564

Imeokparia, D. D., Suh, K. W., and Stobby, W. G. (2002). “Cellular materials," in: Encyclopedia of Polymer Science and Technology, H. F. Mark (ed.), Wiley, Hoboken, NJ, pp.418-473.

Grand View Research (2018). Insulation Market Size \& Share Analysis Report By Product (Glass Wool, Mineral Wool, EPS, XPS), By Application (Residential Construction, Non-residential Construction, Industrial, HVAC \& OEM), And Segment Forecasts, 2018 - 2025, Grand View Research, San Francisco, CA.

Jiang, X., Liu, J., Du, X., Hu, Z., Chang, H.-m., and Jameel, H. (2018). "Phenolation to improve lignin reactivity towards thermosets application," ACS Sustain. Chem. Eng. 6(4), 5504-5512. DOI: 10.1021/acssuschemeng.8b00369

Kaszonyi, A., Hronec, M., Lauko, L., and Ilavský, J. A. N. (1989). "Study of the activity of Co-Br-Py catalysts during oxidation of $p$-xilene in acetic acid," J. Mol. Catal. 57(1), 105-112. DOI: 10.1016/0304-5102(89)80130-0

Kim, B. G., and Lee, D. G. (2008). "Development of microwave foaming method for phenolic insulation foams," J. Mater. Process. Technol. 201(1-3), 716-719. DOI: 10.1016/j.jmatprotec.2007.11.143

Kleinert, M., and Barth, T. (2008). "Phenols from lignin," Chem. Eng. Technol. 31(5), 736-745. DOI: $10.1002 /$ ceat.200800073

Knudsen, K. E. B. (1997). "Carbohydrate and lignin contents of plant materials used in animal feeding," Anim. Feed Sci. Tech. 67(4), 319-338. DOI: 10.1016/S03778401(97)00009-6

Kong, X., Xu, Z., Guan, L., and Di, M. (2014). "Study on polyblending epoxy resin adhesive with lignin I-curing temperature," Int. J. Adhes. Adhes. 48, 75-79. DOI: 10.1016/j.ijadhadh.2013.09.003

Laurichesse, S., and Avérous, L. (2014). "Chemical modification of lignins: Towards biobased polymers," Prog. Polym. Sci. 39(7), 1266-1290. DOI: 10.1016/j.progpolymsci.2013.11.004

Lee, S.-H., Teramoto, Y., and Shiraishi, N. (2002). "Resol-type phenolic resin from liquefied phenolated wood and its application to phenolic foam," J. Appl. Polym. Sci. 84(3), 468-472. DOI: 10.1002/app.10018

Lee, S.-T., Park, C. B., and Ramesh, N. S. (2007). Polymeric Foams: Science and Technology, Taylor \& Francis Group, Boca Raton, FL.

Li, B., Wang, Y., Mahmood, N., Yuan, Z., Schmidt, J., and Xu, C. C. (2017). "Preparation of bio-based phenol formaldehyde foams using depolymerized hydrolysis lignin," Ind. Crop. Prod. 97, 409-416. DOI: 10.1016/j.indcrop.2016.12.063

Li, J., Wang, W., Zhang, S., Gao, Q., Zhang, W., and Li, J. (2016). "Preparation and characterization of lignin demethylated at atmospheric pressure and its application in fast curing biobased phenolic resins," RSC Adv. 6(71), 67435-67443. DOI: 10.1039/C6RA11966B

Li, Y., and Ragauskas, A. J. (2012). "Kraft lignin-based rigid polyurethane foam," J. Wood Chem. Technol. 32(3), 210-224. DOI: 10.1080/02773813.2011.652795

Mainka, H., Täger, O., Körner, E., Hilfert, L., Busse, S., Edelmann, F. T., and Herrmann, 
A. S. (2015). "Lignin - An alternative precursor for sustainable and cost-effective automotive carbon fiber," Journal of Materials Research and Technology 4(3), 283296. DOI: 10.1016/j.jmrt.2015.03.004

Malutan, T., Nicu, R., and Popa, V. I. (2008). "Contribution to the study of hydroxymetylation reaction of alkali lignin," BioResources 3(1), 13-20. DOI: 10.15376/biores.3.1.13-20

Mankar, S. S., Chaudhari, A. R., and Soni, I. (2012). "Lignin in phenol-formaldehyde adhesives," International Journal of Knowledge Engineering 3(1), 116-118.

Markets \& Markets (2015). Cold Insulation Market by Material (Fiber Glass, Phenolic Foams, Polystyrene Phe Foams, Polyurethane Foams, and Others), by End - Use Industry (Chemicals, HVAC, Oil \& Gas, Refrigeration, and Others) - Trends \& Forecasts to 2020, MarketsandMarkets ${ }^{\mathrm{TM}}$, Pune, Maharashtra.

Marton, J., and Adler, E. (1963). “Oxidative demethylation of lignin,” U. S. Patent No. 3071570A.

Matsushita, Y., Imai, M., Iwatsuki, A., and Fukushima, K. (2008). "The relationship between surface tension and the industrial performance of water-soluble polymers prepared from acid hydrolysis lignin, a saccharification by-product from woody materials," Bioresource Technol. 99(8), 3024-3028. DOI: 10.1016/j.biortech.2007.06.015

Nada, A. M. A., El-Saied, H., Ibrahem, A. A., and Yousef, M. A. (1987). "Waste liquors from cellulosic industries. IV. Lignin as a component in phenol formaldehyde resol resin,” J. Appl. Polym. Sci. 33(8), 2915-2924. DOI: 10.1002/app.1987.070330824

Nakamura, Y., Sungusia, M. G., Sawada, T., and Kuwahara, M. (1999). "Lignindegrading enzyme production by Bjerkandera adusta immobilized on polyurethane foam," J. Biosci. Bioeng. 88(1), 41-47. DOI: 10.1016/S1389-1723(99)80173-X

Nenkova, S., Vasileva, T., and Stanulov, K. (2008). "Production of phenol compounds by alkaline treatment of technical hydrolysis lignin and wood biomass," Chem. Nat. Compd. 44(2), 182-185. DOI: 10.1007/s10600-008-9009-z

Obaid, N., Kortschot, M. T., and Sain, M. (2016). "Lignin-based foaming materials," in: Lignin in Polymer Composites, O. Faruk and M. Sain (eds.), William Andrew, Norwich, NY, pp. 217-232.

Pandey, M. P., and Kim, C. S. (2011). "Lignin depolymerization and conversion: A review of thermochemical methods," Chem. Eng. Technol. 34(1), 29-41. DOI: 10.1002/ceat.201000270

Podschun, J., Stücker, A., Saake, B., and Lehnen, R. (2015). "Structure-function relationships in the phenolation of lignins from different sources," ACS Sustain. Chem. Eng. 3(10), 2526-2532. DOI: 10.1021/acssuschemeng.5b00705

Quarles, R. W., and Baumann, J. A. (1967). "Phenolic foam compositions," U. S. Patent No. 3298973A.

Raquez, J.-M., Deléglise, M., Lacrampe, M.-F., and Krawczak, P. (2010). "Thermosetting (bio)materials derived from renewable resources: A critical review," Prog. Polym. Sci. 35(4), 487-509. DOI: 10.1016/j.progpolymsci.2010.01.001

Rastall, M. H., Ng, N. H., and MacPherson, E. J. (1985). "Modified phenolic foams," U. S. Patent No. 4525492A.

Roberts, A. P., and Garboczi, E. J. (2002). "Elastic properties of model random threedimensional open-cell solid," J. Mech. Phys. Solids 50(1), 33-55. DOI:

10.1016/S0022-5096(01)00056-4

Rojas, O. J., Bullón, J., Ysambertt, F., Forgiarini, A., Salager, J.-L., and Argyropoulos, D. 
S. (2007). "Lignins as emulsion stabilizers," in: Materials, Chemicals, and Energy from Forest Biomass, D. S. Argyropoulos (ed.), American Chemical Society, Washington, DC, pp. 182-199.

Schroer, D., Hudack, M., Soderquist, M., and Beulich, I. (2012). Rigid Polymeric Foam Boardstock Technical Assessment, Dow Chemical Company, Midland, MI.

Sen, S., Patil, S., and Argyropoulos, D. S. (2015). "Methylation of softwood kraft lignin with dimethyl carbonate," Green Chem. 17(2), 1077-1087. DOI: 10.1039/C4GC01759E

Song, Y., Wang, Z., Yan, N., Zhang, R., and Li, J. (2016). "Demethylation of wheat straw alkali lignin for application in phenol formaldehyde adhesives," Polymers 8(6), 209. DOI: $10.3390 /$ polym8060209

Stewart, D. (2008). "Lignin as a base material for materials applications: Chemistry, application and economics," Ind. Crop. Prod. 27(2), 202-207. DOI:

10.1016/j.indcrop.2007.07.008

Swain, C. G., Powell, A. L., Shepard, W. A., and Morgan, C. R. (1979). "Mechanism of the Cannizzaro reaction," J. Am. Chem. Soc. 101(13), 3576-3583. DOI: 10.1021/ja00507a023

Tejado, A., Peña, C., Labidi, J., Echeverria, J. M., and Mondragon, I. (2007). "Physicochemical characterization of lignins from different sources for use in phenolformaldehyde resin synthesis," Bioresource Technol. 98(8), 1655-1663. DOI: 10.1016/j.biortech.2006.05.042

Thring, R. W. (1994). “Alkaline degradation of ALCELL® lignin,” Biomass Bioenerg. 7(1-6), 125-130. DOI: 10.1016/0961-9534(94)00051-T

Todorciuc, T., Căpraru, A.-M., Kratochvílová, I., and Popa, V. I. (2009). "Characterization of non-wood lignin and its hydoxymethylated derivatives by spectroscopy and self-assembling investigations," Cell. Chem. Technol. 43(9-10), 399-408.

U.S. EPA (2017). "Formaldehyde emission standards for composite wood products," U.S. Environmental Protection Agency (EPA), Washington, DC.

USDA (2008). U.S. Biobased Products Market Potential and Projections Through 2025 (OCE-2008-1), U.S. Department of Agriculture (USDA), Washington, DC.

Vanholme, R., Demedts, B., Morreel, K., Ralph, J., and Boerjan, W. (2010). "Lignin biosynthesis and structure" Plant Physiology 153(3), 895-905. DOI: 10.1104/pp.110.155119

Vázquez, G., González, J., Freire, S., and Antorrena, G. (1997). "Effect of chemical modification of lignin on the gluebond performance of lignin-phenolic resins," Bioresource Technol. 60(3), 191-198. DOI: 10.1016/S0960-8524(97)00030-8

Wang, G., and Chen, H. (2014). "Phenolic foam prepared by lignin from a steamexplosion derived biorefinery of corn stalk," Chinese Journal of Biotechnology 30(6), 901-910. DOI: 10.13345/j.cjb.140056

Wool, R. P. (2005). "Lignin polymers and composites," in: Bio-based Polymers and Composites, R. P. Wool and X. S. Sun (eds.), Academic Press, Cambridge, MA, pp. 551-598.

Yang, L., Wang, X., Cui, Y., Tian, Y., Chen, H., and Wang, Z. (2014a). "Modification of renewable resources-lignin-by three chemical methods and its applications to polyurethane foams," Polym. Advan. Technol. 25(10), 1089-1098. DOI: 10.1002/pat.3356

Yang, S., Wen, J.-L., Yuan, T.-Q., and Sun, R.-C. (2014b). "Characterization and 
phenolation of biorefinery technical lignins for lignin-phenol-formaldehyde resin adhesive synthesis," RSC Adv. 4(101), 57996-58004. DOI: 10.1039/C4RA09595B

Yuan, Z., Cheng, S., Leitch, M., and Xu, C. C. (2010). "Hydrolytic degradation of alkaline lignin in hot-compressed water and ethanol," Bioresource Technol. 101(23), 9308-9313. DOI: 10.1016/j.biortech.2010.06.140

Zakzeski, J., Bruijnincx, P. C. A., Jongerius, A. L., and Weckhuysen, B. M. (2010). "The catalytic valorization of lignin for the production of renewable chemicals," Chem. Rev. 110(6), 3552-3599. DOI: 10.1021/cr900354u

Zhao, L.-w., Griggs, B. F., Chen, C.-L., Gratzl, J. S., and Hse, C.-Y. (1994). "Utilization of softwood kraft lignin as adhesive for the manufacture of reconstituted wood," $J$. Wood Chem. Technol. 14(1), 127-145. DOI: 10.1080/02773819408003090

Zhuang, X. W., Li, S. H., Ma, Y. F., Zhang, W., Xu, Y. Z., Wang, C. P., and Chu, F. X. (2011). "Preparation and characterization of lignin-phenolic foam," Adv. Mat. Res. 236-238, 1014-1018. DOI: 10.4028/www.scientific.net/AMR.236-238.1014

Article submitted: June 28, 2018; Peer review completed: August 10, 2018; Revised version received and accepted: August 15, 2018; Published: August 27, 2018.

DOI: 10.15376/biores.13.4.Londono-Zuluaga 